\title{
Detection of monoclonal protein by capillary zone electrophoresis can be challenged by iodinated contrast agent interference: a case report
}

\author{
Clément Capaldo*1, Mourad Cheddad El Aouni², Damien Laurelli', Cyril Leven¹,3, Jean-Luc Carré1,4 \\ ${ }^{1}$ Department of Biochemistry and Pharmaco-Toxicology, University Hospital of Brest, Brest, France \\ ${ }^{2}$ Neuroradiology Unit, Department of Radiology, University Hospital of Brest, Brest, France \\ 3Univ Brest, EA 3878, GETBO, Brest, France \\ ${ }^{4}$ Univ Brest, EA 4685, LIEN, Brest, France \\ *Corresponding author: clement.capaldo@chu-brest.fr
}

\begin{abstract}
The detection of monoclonal immunoglobulins is a key element in the diagnosis of monoclonal gammopathy. In clinical practice, screening and measurement of monoclonal proteins are commonly performed using capillary zone electrophoresis (CZE). Some exogenous substances, such as iodinated contrast agents, absorb incident UV light at the same wavelengths as the peptide bonds and may therefore interfere with the detection of proteins in CZE. We herein use the description of a case to illustrate that iodinated contrast agents can mask the presence of monoclonal immunoglobulins in CZE and we discuss the strategy needed to confirm this interference. Performing immunofixation, immunosubtraction, or a second CZE at a distance from the first blood sample is not only necessary to confirm the presence of an iodinated contrast media interference but also to ensure the absence of monoclonal proteins.
\end{abstract}

Keywords: capillary electrophoresis; interference; iodinated contrast; gammopathy; case report

\section{Introduction}

The detection of monoclonal proteins remains essential in the management of monoclonal gammopathy for diagnosis, risk stratification, therapeutic assessment, and monitoring of disease progression (1). In clinical practice, screening and measurement of monoclonal proteins are commonly performed using capillary zone electrophoresis (CZE). Some exogenous substances, such as iodinated contrast agents, absorb incident UV light at the same wavelengths as the peptide bonds and may therefore interfere with the detection of proteins in CZE (2). lodinated contrast agents show a supernumerary peak in $\beta$ - and a-globulin fraction using CZE which may erroneously suggest the presence of monoclonal immunoglobulin (3). We herein use the description of a case to illustrate the need to explore interferences with iodinated contrast agents in order not to ignore the presence of monoclonal immunoglobulin.

\section{Case Report}

We report the case of a 90-year-old woman with no haematological history who was admitted to a neurovascular intensive care unit for suspected stroke. The patient had a left sensory-motor deficit and speech impairment. The blood sample was taken 8 hours after a computed tomography angiography and thrombectomy. Serum protein electrophoresis was performed on CAPILLARYS 2 (Sebia, Lisses, France). A duplication of the $\beta$-2 globulin fraction (black arrow) with an increase in concentration to $7.4 \mathrm{~g} / \mathrm{L}$ (reference interval: 2.3-4.7 $\mathrm{g} / \mathrm{L}$ ) and a shoulder of $\beta-1$ globulin (grey arrow) 
were detected compared to normal serum (Figure 1A). Other laboratory results were unremarkable (Table 1). An informed consent form for the publication of a case report was signed by the patient during hospitalization.

\section{Further investigations}

To explain the duplication of the $\beta-2$ globulin fraction, we hypothesized that we detect the radioopaque agent that was administered during the angiography (iomeprol) as previously reported (4). We performed immunofixation (HYDRAGEL, SEBIA, France) and immunosubtraction (CAPILLARYS 2, SEBIA, France) to test this hypothesis. IgG Kappa immunoglobulin was detected through immunofixation (Figure 1B) and immunosubtraction (Figure $1 C$ ) in the $\beta-2$ globulin fraction. Second protein electrophoresis (Figure 1D), performed on a sample taken 6 days after iomeprol injection, showed
TABLE 1. Laboratory findings at first admission

\begin{tabular}{lcc}
\hline Parameter (unit) & Result & Reference interval \\
\hline Creatinine $(\mu \mathrm{mol} / \mathrm{L})$ & 33 & $40-66$ \\
\hline Haemoglobin $(\mathrm{g} / \mathrm{L})$ & 131 & $120-160$ \\
\hline Mean cell volume $(\mathrm{fL})$ & 89 & $82-98$ \\
\hline Calcium $(\mathrm{mmol} / \mathrm{L})$ & 2.07 & $2.08-2.65$ \\
\hline Albumin $(\mathrm{g} / \mathrm{L})$ & 35 & $34-50$ \\
\hline Total protein $(\mathrm{g} / \mathrm{L})$ & 64 & $57-82$ \\
\hline $\operatorname{lgG}(\mathrm{g} / \mathrm{L})$ & 13.0 & $6.1-13.0$ \\
\hline $\operatorname{lgA}(\mathrm{g} / \mathrm{L})$ & 3.2 & $0.4-3.5$ \\
\hline $\operatorname{lgM}(\mathrm{g} / \mathrm{L})$ & 1.2 & $0.5-3.0$ \\
\hline
\end{tabular}

IgG - immunoglobulin G. IgA - immunoglobulin A. IgM immunoglobulin $\mathrm{M}$.
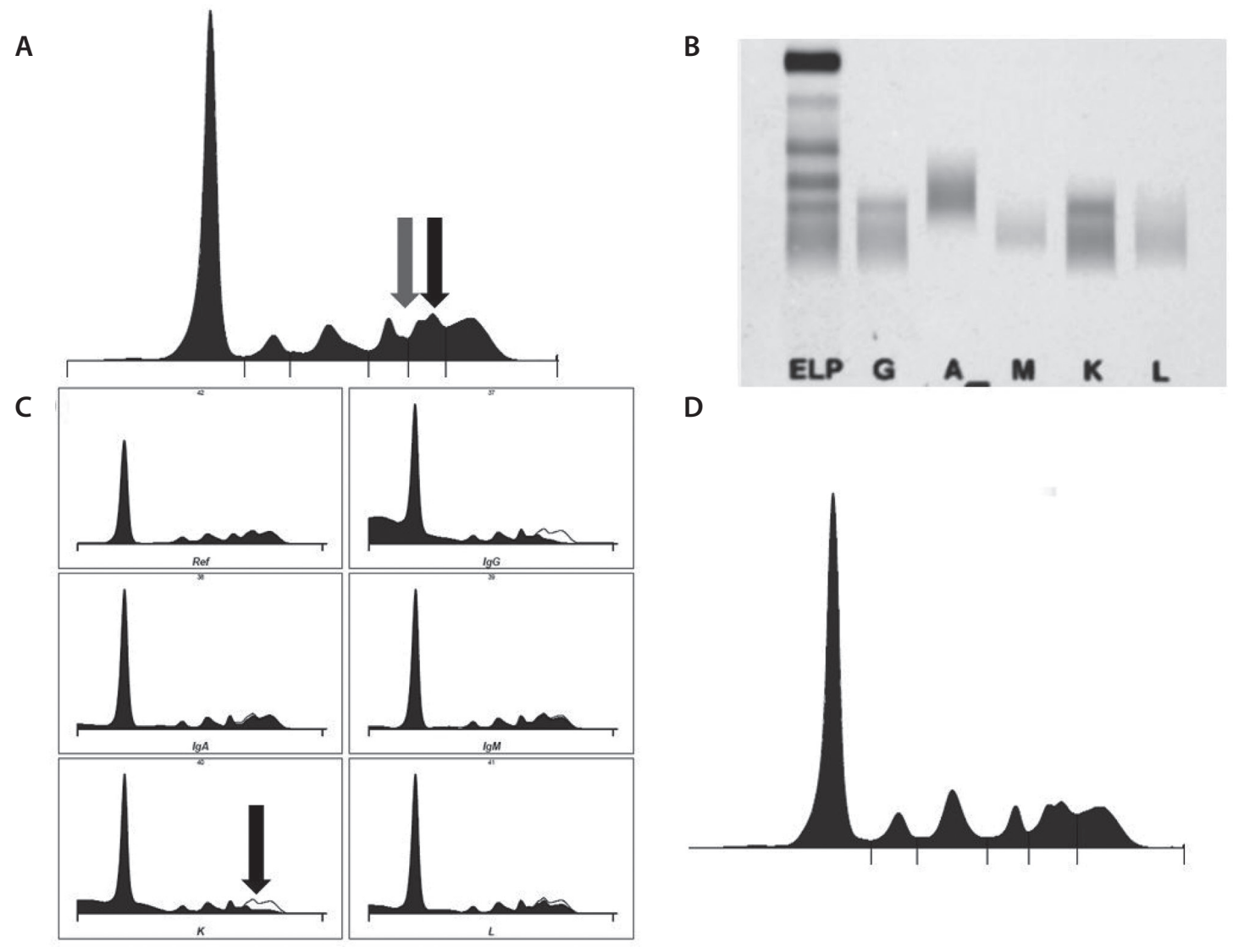

D

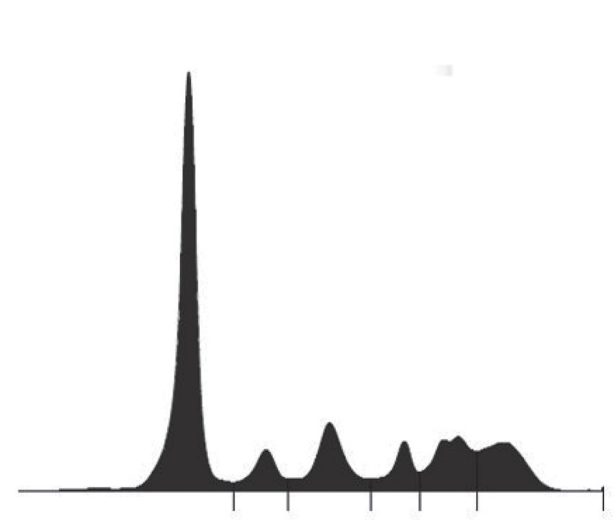

Figure 1. Results of capillary zone electrophoresis (A), immunofixation (B) and immunosubtraction (C) collected 8 hours after injection of iomeprol. Results of capillary zone electrophoresis collected 6 days after injection of iomeprol (D). 
no $\beta-1$ globulin shoulder as opposed to the electrophoresis of the first sample, suggesting interference with the iodinated contrast agent. The absence of reaction with anti-lgG, $-\lg A,-\lg M,-K_{1}-\lambda$ antibodies to the $\beta-1$ globulin fraction on immunosubtraction (Figure 1C) and immunofixation (Figure 1B) supported the presence of interference. To confirm the location of the iomeprol peak following electrophoresis on the CAPILLARYS 2 analyser, iomeprol was added to normal serum concentrations (Figure 2). The migration zone of iomeprol on the CAPILLARYS 2 analyser matched the location of the $\beta 1$-globulin shoulder observed on the first electrophoresis (Figure 1A).

\section{What happened?}

Finally, further analysis demonstrated that the duplication of the $\beta-2$ globulin fraction corresponded to monoclonal IgG Kappa and that te shoulder of the $\beta-1$ globulin fraction was due to interference by iomeprol.
A

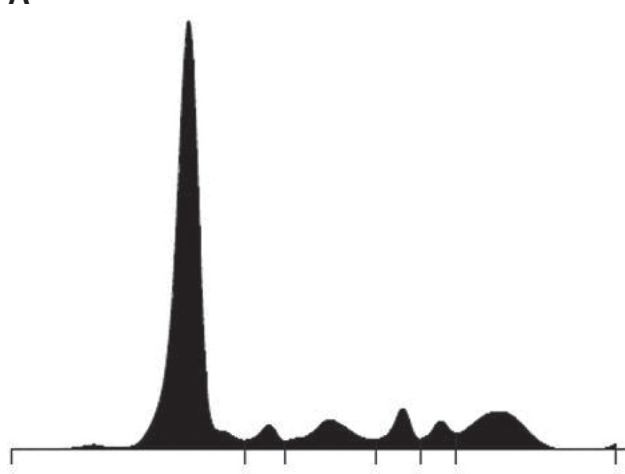

B

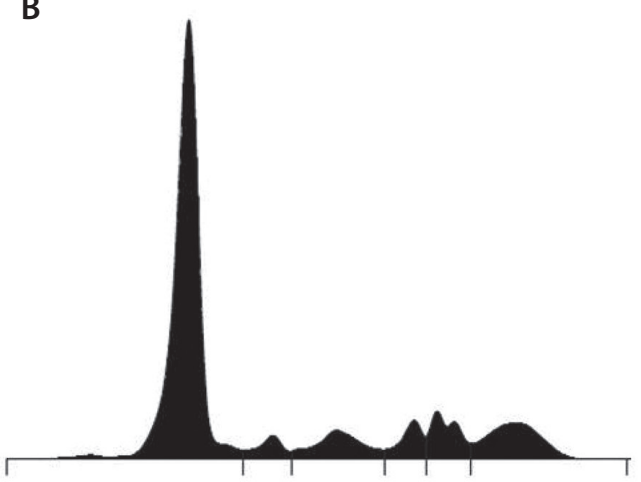

FIGURE 2. Results of capillary electrophoresis on normal serum concentrations (A) and normal serum spiked with iomeprol (B).

\section{Discussion}

Interference with iodinated contrast media is generally described as responsible for the appearance of false positive peaks in CZE (5). This observation shows that such interference can also mask the possible presence of monoclonal immunoglobulin. Indeed, monoclonal proteins and iodinated contrast agents can migrate to the same electropherogram fraction using capillary zone electrophoresis. On the one hand, in a cohort of 1027 myeloma multiple patients, the monoclonal protein migration was distributed in $12 \%$ in the $\beta$-fraction and $1 \%$ in the $\alpha-2$ fraction (6). On the other hand, Arranz-Pena et al. described that a number of radio-opaque agents cause interference with the peak in the a2-globulin fraction, $\beta$-fraction, and pre-albumin (3). Further investigation is required to confirm the suspicion of interference so that the presence of monoclonal proteins at the CZE is not ignored. Interference with the radio-opaque product is easily confirmed by the absence of a monoclonal abnormality on immunofixation, immunosubtraction or by the disappearance of the supernumerary peak on a later sample for CZE analysis. Since the clearance of iodinated contrast agents is essentially renal, the size of the supernumerary peak depends on the patient's renal function and the time between sampling and imaging (7). It is also possible to optimize the blood collection protocol to prevent interference and avoid further unnecessary studies by spacing intervals of 24 hours between blood sampling and the image examination, or 48 hours in case of renal failure (8).

In our hospital, the incidence of suspected interferences with iodinated contrast agents was low in 
2019 (3.2\%o of the sample submitted for CZE) and was comparable to other centres $(8,9)$. All suspicions of interference were tested or signalled to the clinicians associated with the recommendation to test the hypothesis by performing a second sampling.

In this case and according to the recommendations of the International Myeloma Working Group (IMWG), monoclonal gammopathy of undetermined significance (MGUS) was diagnosed in view of the monoclonal protein concentration $<30 \mathrm{~g} / \mathrm{L}$ and the absence of organ damage due to plasma cell proliferation (hypercalcaemia, renal failure, anaemia, bone damage) (1). A myelogram was not proposed due to the advanced age of the patient and the poor expected benefits.

In conclusion, we would like to remind that iodinated contrast agents can mask the presence of monoclonal immunoglobulins migrating into the

\section{References}

1. The International Myeloma Working Group. Criteria for the classification of monoclonal gammopathies, multiple myeloma and related disorders: a report of the International Myeloma Working Group. Br J Haematol. 2003;121:749-57. https://doi.org/10.1046/j.1365-2141.2003.04355.x

2. Lippi G, Daves M, Mattiuzzi C. Interference of medical contrast media on laboratory testing. Biochem Med (Zagreb). 2014;24:80-8. https://doi.org/10.11613/BM.2014.010

3. Arranz-Peña ML, González-Sagrado M, Olmos-Linares $A M$, Fernández-García N, Martín-Gil FJ. Interference of iodinated contrast media in serum capillary zone electrophoresis. Clin Chem. 2000;46:736-7. https://doi.org/10.1093/ clinchem/46.5.736

4. Vermeersch P, Mariën G, Bossuyt X. Pseudoparaproteinemia related to lomeprol administration after angiocardiography: detection in the $\beta$ fraction by capillary zone electrophoresis. Clin Chem. 2006;52:2312-3. https://doi. org/10.1373/clinchem.2006.078584

5. Cho SY, Kim Y, Lee A, Park TS, Lee HJ, Suh JT. Three cases showing false results in the detection of monoclonal compo- $\beta$ - and a-globulin fraction using CZE. Performing immunofixation, immunosubtraction, or a second CZE at a distance from the first blood sample. Not only is necessary to confirm the presence of iodinated contrast media interference but also to ensure the absence of monoclonal proteins.

\section{What you should / can do in your laboratory to prevent such errors}

- Always perform further investigation in case of suspicion of interference with iodinated contrast agents.

- Interferences can be highlighted by immunofixation, immunosubtraction or a second CZE at a distance from the first blood sample.

\section{Potential conflict of interest}

None declared. nents using capillary electrophoresis. Lab Med. 2011;42:6026. https://doi.org/10.1309/LMHZLIMXVYLWT7SQ

6. Kyle RA, Gertz MA, Witzig TE, Lust JA, Lacy MQ, Dispenzieri $A$, et al. Review of 1027 patients with newly diagnosed multiple myeloma. Mayo Clin Proc. 2003;78:21-33. https://doi. org/10.4065/78.1.21

7. Barakian BF, Martínez, VJ, Tommasi CA, Gorino N, Borgonovo A, Bresciani PD, Madalena L. [Interferencia por iopamidol en el proteinograma por elecroforesis capilar y su relación con la función renal]. Rev de Nefrol Dialisis y Transpl. 2019;39:93-100. (in Spanish)

8. Quirós C, Cillero Al, Bretaña L, García M, Prieto B, Álvarez FV. In vivo interference of loversol in serum and urine capillary electrophoresis: an optimized protocol for sample collection. Clin Chem Lab Med. 2018;56:e53-5. https://doi. org/10.1515/cclm-2017-0509

9. Wils J, Lavoinne A, Vaillant C. Detecting a peak in fraction beta by capillary electrophoresis: interference due to iomeprol. Ann Biol Clin (Paris). 2013;71:196-8. https://doi. org/10.1684/abc.2013.0799 